Habitat suitability models for the conservation of thermophilic grasshoppers and bush crickets simple or complex?

\author{
Review Article \\ Author(s): \\ Hein, Silke; Voss, Julia; Poethke, Hans-Joachim; Schroeder, Boris \\ Publication date: \\ 2007-09 \\ Permanent link: \\ https://doi.org/10.3929/ethz-b-000067144
}

Rights / license:

In Copyright - Non-Commercial Use Permitted

Originally published in:

Journal of Insect Conservation 11(3), https://doi.org/10.1007/s10841-006-9038-5 


\title{
Habitat suitability models for the conservation of thermophilic grasshoppers and bush crickets-simple or complex?
}

\author{
Silke Hein · Julia Voss · Hans-Joachim Poethke • \\ Boris Schröder
}

Received: 7 April 2006/ Accepted: 2 August 2006/Published online: 5 December 2006

(C) Springer Science+Business Media B.V. 2006

\begin{abstract}
One goal of conservation biology is the assessment of effects of land use change on species distribution. One approach for identifying the factors, which determine habitat suitability for a species are statistical habitat distribution models. These models are quantitative and can be used for predictions in management scenarios. However, they often have one major shortcoming, which is their complexity. This means that they need several, often costly-to-determine parameters for predictions of species occurrence. We first used habitat suitability models to investigate and determine habitat preferences of three different Orthoptera species. Second, we compared the predictive powers of simple habitat suitability models considering only the 'habitat type' as predictor with more complex models taking different habitat factors into account. We found that the habitat type is the most reliable and robust factor, which determines the occurrence of the species studied. Thus, analyses of habitat suitability can easily be carried out on the basis of existing vegetation maps for the conservation of the three species under study. Our results can serve as a basis for the estimation of spatio-temporal distribution
\end{abstract}

S. Hein $\cdot$ J. Voss $\cdot$ H.-J. Poethke

Ecological Field Station, University of Würzburg,

Würzburg, Germany

Present Address:

S. Hein $(\triangle)$

Institute of Plant Sciences/Applied Entomology, ETH

Zurich, Schmelzbergstr. 9/LFO, CH-8092, Zurich

e-mail: silke.hein@ipw.agrl.ethz.ch

B. Schröder

Institute of Geoecology, University of Potsdam, Potsdam,

Germany and survival probabilities of the species studied and might also be valuable for other species living in dry grasslands.

Keywords Conservation - Habitat selection modelling $\cdot$ Dry grassland $\cdot$ Semi-arid grassland · Model simplicity

\section{Introduction}

Anthropogenic land use has contributed to a diversification of the landscape (Settele 1998), while increasing land use has created new habitats for animal and plant species (Huston 1994; Mühlenberg et al. 1996). In Central Europe, species of nature conservation concern, as well as high species diversity in general have been mainly found in extensively managed areas (Kull and Zobel 1991; Bignal and McCracken 1996). The landscape pattern has remained static, since most areas have been utilised in the same way over many years and even centuries. However, due to increased economic pressure, extensively managed areas are nowadays either abandoned and lie fallow, or are fertilized and intensively used (Mühlenberg et al. 1996). In both cases, rare and protected plant and animal species become extinct due to natural succession or increased disturbance (Fuller 1987; Vos and Zonnefeld 1993; Beaufoy et al. 1994; Poschlod et al. 1996).

Within Central Europe these problems apply particularly to dry grasslands such as the ones in the nature reserve 'Hohe Wann' in Central Germany, which have only a low agricultural productivity (Van Dijk 1991; Poschlod et al. 1996). On the one hand, 
these grasslands require some level of disturbance to increase small scale environmental heterogeneity and thus species diversity (Huston 1994; McConnaughay and Bazzaz 1987; Jacquemyn et al. 2003). On the other hand, disturbance should not exceed a certain level, with increased management intensity leading to species diversity decline (Kruess and Tscharntke 2002).

For conservation of these areas, different management regimes have been suggested, such as goat and/or cattle grazing, rototilling, burning and mowing (e.g. Schreiber 1977; Bakker 1989; Bobbink and Willems 1993; Kahmen et al. 2002; Kleyer et al. 2002; Redecker et al. 2002). Different management regimes with different return intervals result in a landscape consisting of a mosaic of different habitat patches, with habitat quality constantly changing over time.

For the protection and conservation of insect populations in such dynamic, fragmented landscapes, it is important to know at what successional time a patch is of ideal, or at least acceptable suitability for a specific species or species assemblage. To predict which successional stages are suitable for specific species, reliable information on species-specific habitat requirements are needed. In general, such information is a critical prerequisite for the choice of protected areas, the design of management strategies, and the assessment of possible effects of various landuse changes on the survival of plant and animal species (Fielding and Haworth 1995; Oppel et al. 2004).

In recent years, statistically derived habitat suitability models have become a common tool for the estimation of critical factors, which determine habitat suitability and habitat selection by a species (Lindenmayer et al. 1991; Pearce et al. 1994; Guisan and Zimmermann 2000; Rushton et al. 2004). Such models formalize the relationship between the occurrence of a species and characteristics of a site (Guisan and Zimmermann 2000; Austin 2002) and may be a cost effective alternative to monitoring (Owen 1989; Fraser 1998).

The development of multi-parameter logistic regression models representing several facets of the realised niche investigates habitat preferences of the (insect) species under study in great detail. Unfortunately, such detailed information is not usually available in practical conservation biology and requires enormous amounts of time-consuming field work. In addition, predictors may vary depending on spatial scale, so that different parameters for different questions need to be determined. Thus, for applied conservation biology, one would like to know a few, easy-to-measure, integrative parameters for the prediction of habitat suitability. Such parameters should ideally be independent of spatial scale. Examples are the management type as well as the habitat type, which are often the only landscape-wide information readily available. Thereby, the habitat type describes the type of vegetation that is typically found in an area, such as dry grassland or forest. Thus, it comprises many aspects of the realised niche of (insect) species living in such areas with regard to abiotic and biotic conditions as well as disturbance regimes.

In contrast to butterflies and some other insect species, grasshoppers and bush crickets are generally regarded as food generalists (i.e. polyphagous to omnivorous, Detzel 1998) and are therefore not usually limited by food resources in natural habitats. Habitat capacity is therefore likely to be determined by other factors such as oviposition sites or ambient temperature. In temperate zones most grasshoppers and bush crickets occur in dry and open habitats with the highest diversity in warm lowland habitats (Detzel 1998). These areas are the focus of many nature conservation efforts in Europe (Poschlod and Schumacher 1998; Pykälä 2003). In open grasslands, grasshoppers and bush crickets utilise different structures during their life cycle such as long lawn structures for food or shelter and short lawn areas with increased temperature for egg development. Grasshoppers and bush crickets are therefore good indicators of structural heterogeneity. Consequently, their habitat requirements cover the habitats of a variety of different other animal species in open grasslands.

In this study, we develop statistical habitat suitability models for the two bush cricket species Platycleis albopunctata and Metrioptera bicolor (PHILIPPI 1796; Orthoptera: Tettigoniidae) as well as for the grasshopper Stenobothrus lineatus (PANZER 1796) (Orthoptera: Acrididae). All three species are typically found on dry grassland. For the development of the models we first use readily available information such as the habitat type. Secondly, we select biotic and abiotic site parameters which are relevant to the habitat preferences of the three species and thus develop more complex multiple models that include specific plot parameters, like vegetation, topography or soil characteristics. Finally, the predictive performances of both types of models are compared to quantify the trade-off between practical applicability and conservation issues. 


\section{Methods}

The species

From literature a general 'expert opinion' on the habitat requirements of the three species can be formed. However, these opinions have not yet been confirmed by thorough field studies of the kind presented in this article (for another method see Lele and Allen 2006). All three species studied are at their northern distribution limit in Germany and thus, might chose distinct habitats within their core distribution area. Current knowledge on species habitat requirements, threat status and distribution can be summarised as follows:

\section{Stenobothrus lineatus}

The stripe-winged grasshopper Stenobothrus lineatus (PANZER 1796) (Orthoptera: Acrididae) is a medium to large-sized grasshopper species (body length: 15$26 \mathrm{~mm}$ ). It is thermophilic and xerophilic and inhabits arid and semi-arid grasslands as well as broom heath, juniper heath, and short lawn edges of woods. Sheepgrazed areas and short vegetation structures are its preferred habitat elements (Detzel 1998). S. lineatus originates from Sibiria and has a euro-asiatic distribution (Detzel 1998; Maas et al. 2002). Populations are reported from France, Southern England, Spain, Italy, Poland and the CIS-countries (Maas et al. 2002). S. lineatus is common in South- and Mid-Germany but in North-/Northwest-Germany particularly in the coastal regions, this species only occurs in small populations. Here we find the northern distribution range of the species in Germany. S. lineatus is not mentioned in the Red List of Germany (1997), but has been given a 'near threatened' status and classified as vulnerable according to Red List of Bavaria, the study region (Bayerisches Landesamt für Umweltschutz 2003).

\section{Metrioptera bicolor}

The two-colored bush cricket Metrioptera bicolor (PHILIPPI 1796; Orthoptera: Tettigoniidae) is medium-sized (body length: 15-18 mm), thermophilic and xerophilic, and mainly inhabits dry grasslands. As it orientates towards vertical structures, the species prefers longlawn biotopes. $M$. bicolor can also be found on juniper heath, poor grasslands, semi-arid and sandy grasslands (Detzel 1998). Kindvall and Ahlen (1992) describe the species as sedentary as it does not often leave its native habitat patches. In the Red List of
Germany (1997) M. bicolor is not mentioned and can therefore be regarded as not endangered or threatened. Its conservation status according to Red List of Bavaria (Bayerisches Landesamt für Umweltschutz 2003 ) is vulnerable. The northern distribution range of M. bicolor in Germany runs from Northern RhinelandPalatinate via South-Hesse, Thuringia to Brandenburg, where only scattered distributed populations can be found. The overall distribution range of M. bicolor is from the Ural to France and from Southern Sweden to Northern Italy (Maas et al. 2002).

\section{Platycleis albopunctata}

The grey bush cricket Platycleis albopunctata (GOEZE 1778; Orthoptera: Tettigoniidae) is a medium- to largesized bush cricket species (body length: $18-22 \mathrm{~mm}$ ). It is classified as a thermophilic and xerophilic species (Harz 1969; Ingrisch and Köhler 1998), which inhabits dry locations, especially mesobromion (Detzel 1998). Open soil, sparse vegetation and fringes are its preferred habitat elements. P. albopunctata is rated as 'near threatened' for the Red List of Germany (1997). In Bavaria it is considered 'vulnerable' (Ingrisch and Köhler 1998, Bayerisches Landesamt für Umweltschutz 2003). P. albopunctata is mainly distributed in West and Central Europe. The eastern distribution border runs from Silesia to the Northern range of the Alps in Lower Austria. In Western Europe the species is distributed across Portugal, Spain, France and Southern England. The most northern populations have been reported in Southern Scandinavia. Its distribution in Germany is very scattered and the Atlantic regions of Northwest Germany are not colonized. In South and Eastern Germany the species is more abundant in the warmer regions. In Bavaria the species is restricted to the north.

\section{Field work}

The study was conducted in August and September 2001 and 2002 in the nature reserve 'Hohe Wann' in Northern-Bavaria, Germany (latitude $50^{\circ} 03^{\prime}$, longitude $10^{\circ} 35^{\prime}$ ). The study area is characterised by a patchwork of vegetation caused by the geological and geomorphological heterogeneity of the area. Smallscale microclimatic differences are caused by differences in inclination, insolation and land use. The most obvious characteristic of the nature reserve is an abundance of dry grassland, formerly used as vine yards (Elsner 1994). These patches are separated by small agricultural fields of different use resulting in a 
patchy mosaic of different habitat types. The whole area covers approximately $10 \mathrm{~km}$ in NS-direction and $4 \mathrm{~km}$ in EW-direction (Binzenhöfer et al. 2005; Rudner et al. 2005).

Incidence of the grasshopper and bush cricket species was recorded on 146 experimental sites selected by stratified random sampling across the ten main habitat types occuring in the region (Table 1). In this study the 'habitat type' describes a landscape unit within the studied landscape characterised by its typical vegetation composition, e.g. forest or dry grassland. To increase the resolution of our approach (Vaughan and Ormerod 2003), we sampled habitats with uncertain status regarding the species' occurrence more intensively (Table 2).

To determine the main habitat types (Table 2) in the area we used a Geographic Information System $\left(\mathrm{ESRI}^{\mathrm{TM}}\right.$ ArcView 3.2). The distance between two experimental sites was at least $30 \mathrm{~m}$. In the field, we characterised each site by the vegetation structure of a randomly chosen $1 \mathrm{~m}^{2}$ plot. For the analysis of micro-structural preference of the grasshoppers and bush crickets vegetation structure was also recorded in $1 \mathrm{~m}^{2}$ plots surrounding the point where individuals of the species under study were found. Vegetation structure analysis included estimates of (i) horizontal plant cover in 10, 20, 30, 40, 50 and $60 \mathrm{~cm}$ heights, (ii) vertical plant cover of moss-, herb- and grass-layers and (iii) mean vegetation height (cf. Sundermeier 1999). Additionally we recorded the habitat type, the current management regime, the inclination and exposition of the plots. To determine the impact of 'landscape' factors such as solar radiation, slope, soil type and geology, these factors were calculated in a digital terrain model and a landscape model (Schröder et al. 2004; Rudner et al. 2005) and included into the analyses.

For the determination of grasshopper and bush cricket incidence we carried out transect sampling (inter-transect distance $=1.5 \mathrm{~m}$ ) on the experimental sites $(15 \times 15 \mathrm{~m})$. The census was terminated either (i) as soon as a specimen was found or (ii) after a maximum of 20 min of sampling. As the activity of grasshoppers and bush crickets strongly depends on weather conditions, we carried out censuses only during 'good' weather conditions (i.e. sunshine, cloud cover $<3 / 8$; air temperature $>17^{\circ} \mathrm{C}$; wind speed $<4 \mathrm{~m} / \mathrm{s}$, according to Mühlenberg 1993) to ensure the same detection probability in all plots.

To test for the transferability of the resulting habitat suitability models in space (cf. Leftwich et al. 1997; Dennis and Eales 1999; Schröder and Richter 1999; Schröder 2000; Fleishman et al. 2003;
Binzenhöfer et al. 2005), we additionally sampled an area approximately $200 \mathrm{~km}$ away from our original study site in the Thuringian nature reserve 'Leutratal' near Jena (latitude $50^{\circ} 52^{\prime}$, longitude $11^{\circ} 34^{\prime}$ ). This area is also characterised by a high fraction of dry grasslands with a wide variety of rare plant and animal species (Heinrich et al. 1998). Here we studied 28 experimental sites across five habitat types (Table 2) in the same manner as in our main study area. $M$. bicolor did not occur in that region, thus the spatial validation of the habitat suitability model for $M$. bicolor was not possible.

Statistical analyses

\section{Development of habitat suitability models}

The distribution, or response of an organism in regard to a given environmental variable is generally considered nonlinear (Gauch and Chase 1974; Austin 1976; Heglund et al. 1994). In recent years logistic regression analysis (GLM for a binomial response variable) has gained importance in the analyses of the relationship between independent variables (habitat parameters) and a dichotomous dependent variable (incidence of a specific species, Trexler \& Travis 1993). This procedure is the only suitable one for an analysis of categorial variables (Capen et al. 1986). In addition, this method is favoured because of better results in the classification of results and the models are more robust compared to those from discriminant analyses. Additionally, coefficients are easy to interpret and a variety of measures for model calibration and discrimination have been developed (Nagelkerke 1991; Buckland et al. 1997; Fielding and Bell 1997; Hosmer and Lemeshow 2000; Manel et al. 2001; Austin 2002).

In our study, we used single and multiple parameter logistic regression models to predict occurrence probabilities depending on plot parameters (Manel et al. 1999a, b; Hosmer and Lemeshow 2000). For the selection of adequate models, we started with an univariate analysis to assess individual predictor variables independently from each other and to obtain information on each predictor's performance (Hosmer and Lemeshow 2000). To choose uncorrelated parameters for the development of multiple parameter models we calculated all pairwise Spearman rank correlations. In cases of pairs showing a strong correlation $\left(\rho_{s} \geq 0.7\right.$, cf. Fielding and Haworth 1995) only the variable delivering the best AUC-value (i.e. the area under a Receiver Operating Characteristic/ROC-curve as a measure of discriminative 

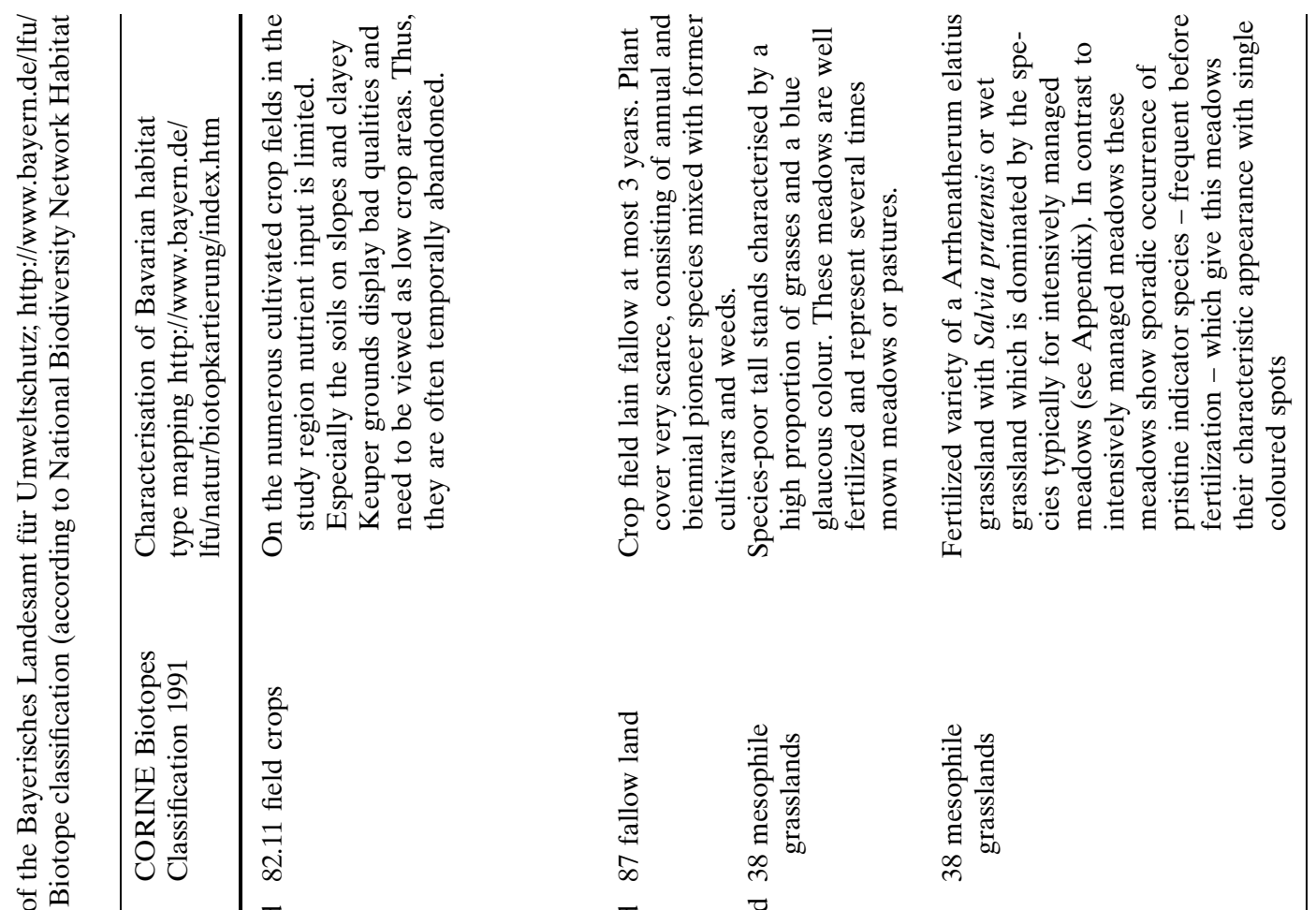

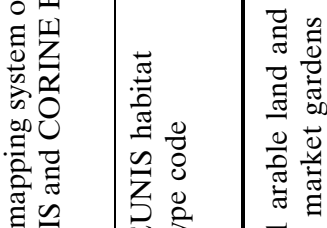

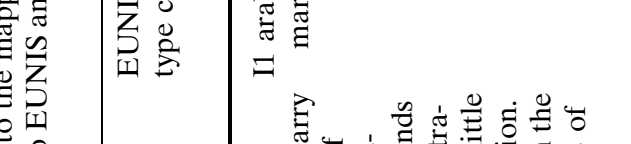

.

चे

胥

党

它离

站

$\Xi$

ฮั

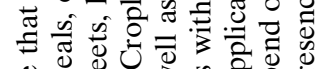

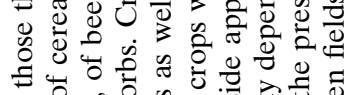

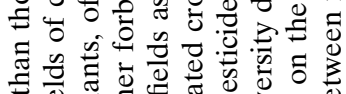

\%

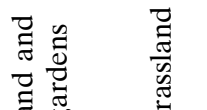

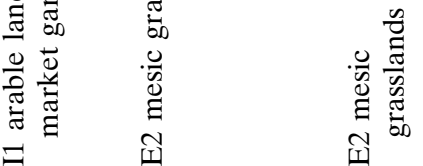

焉.

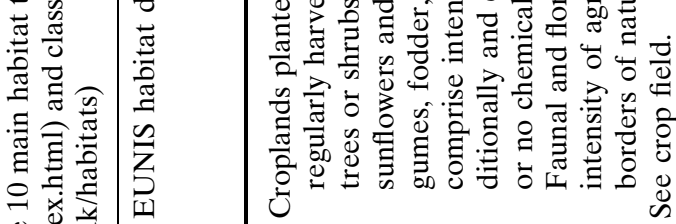

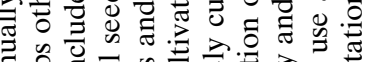

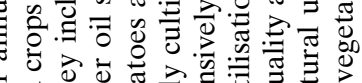

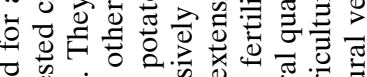

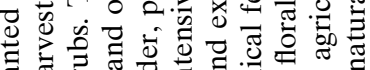

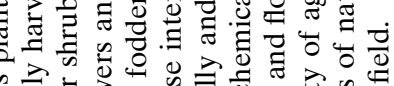

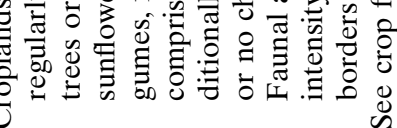<smiles>CCC</smiles>

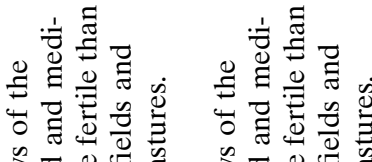

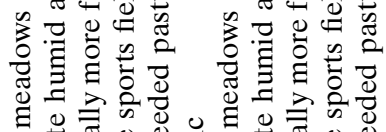

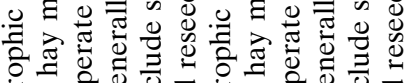

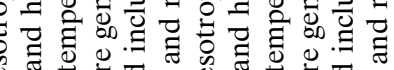

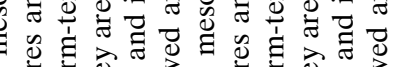

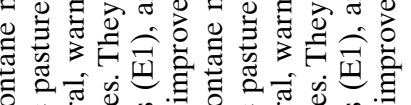

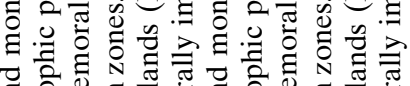
可

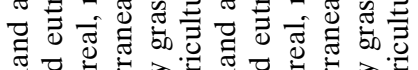

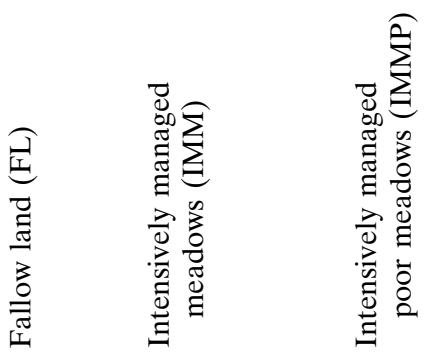




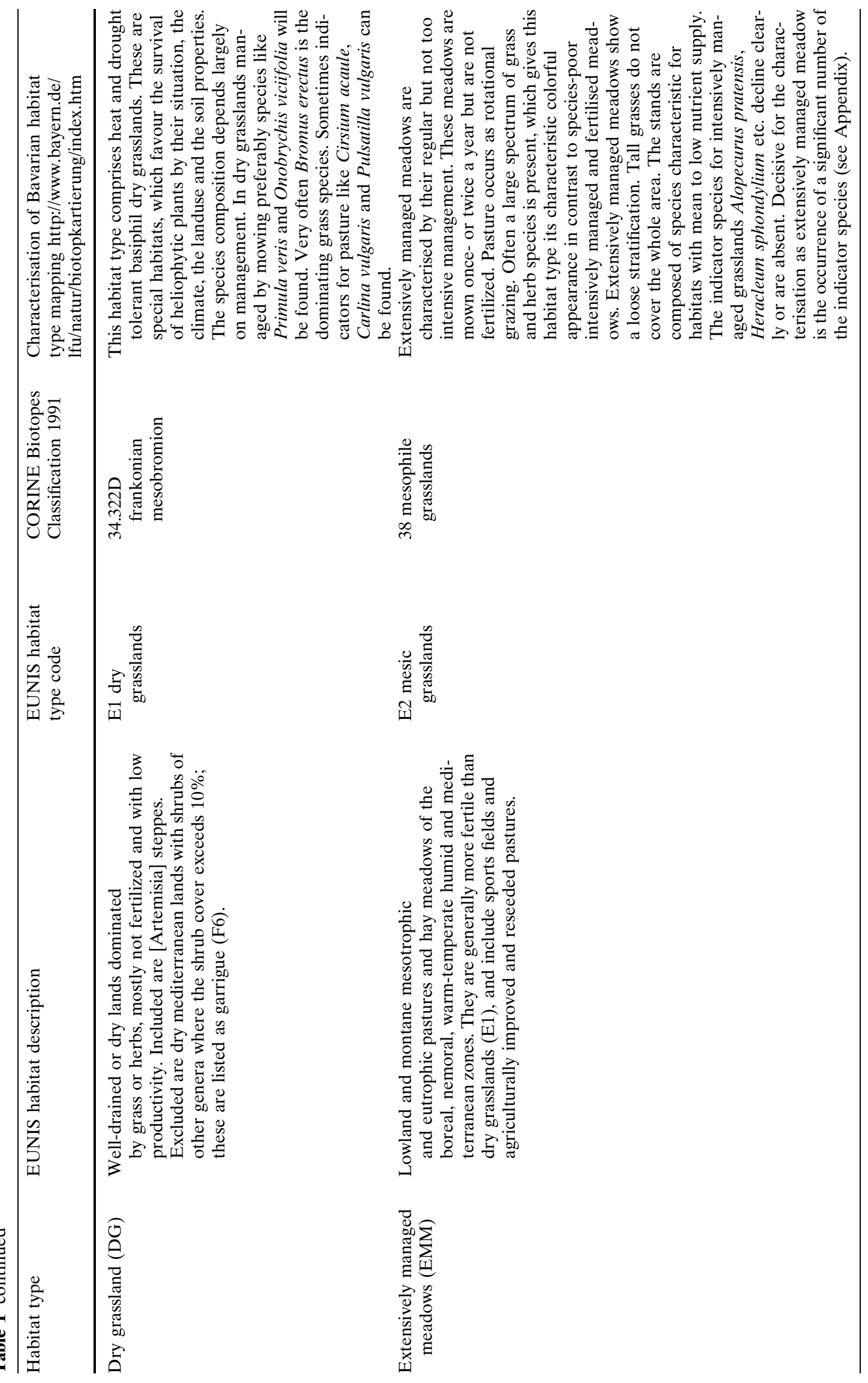




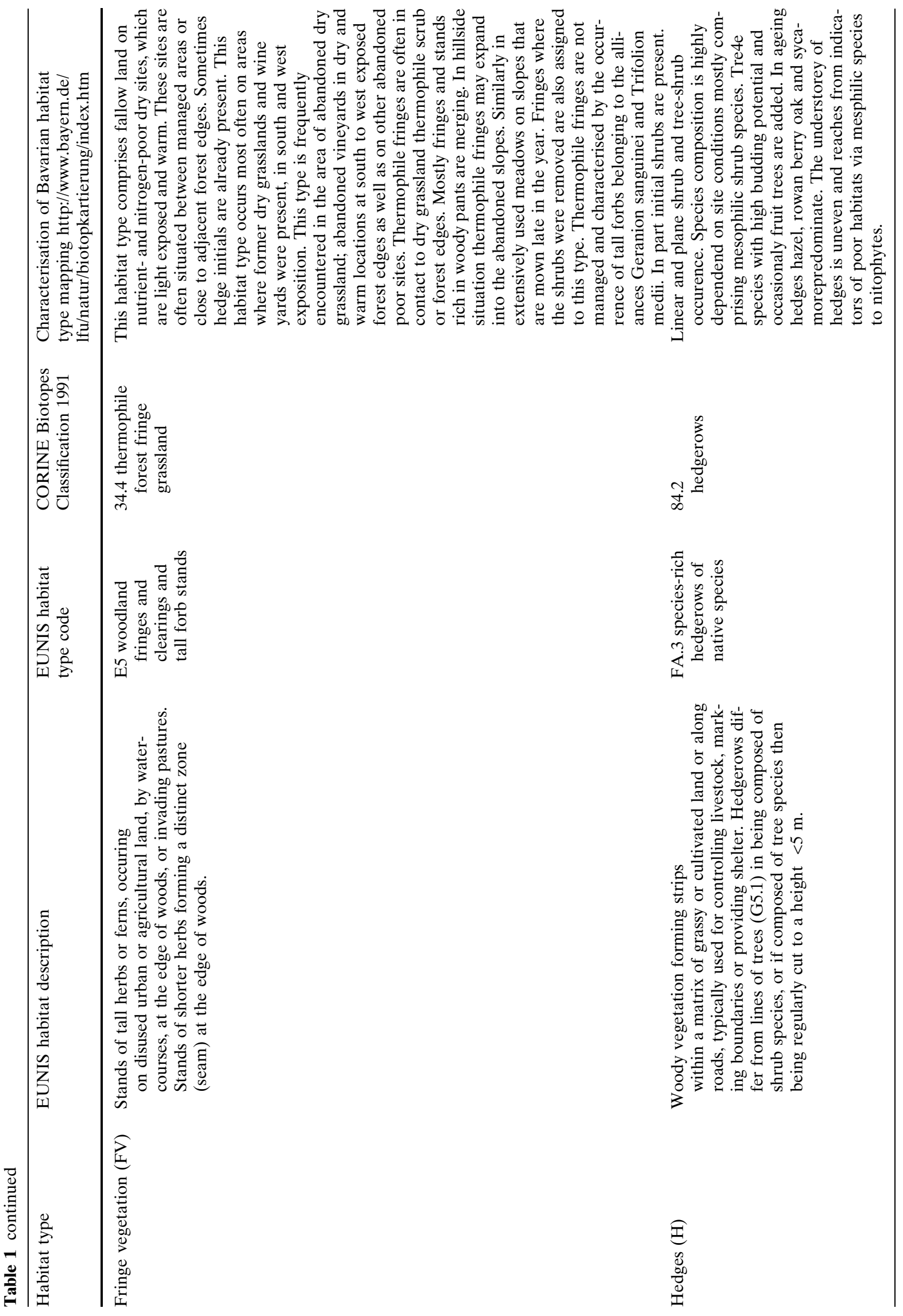




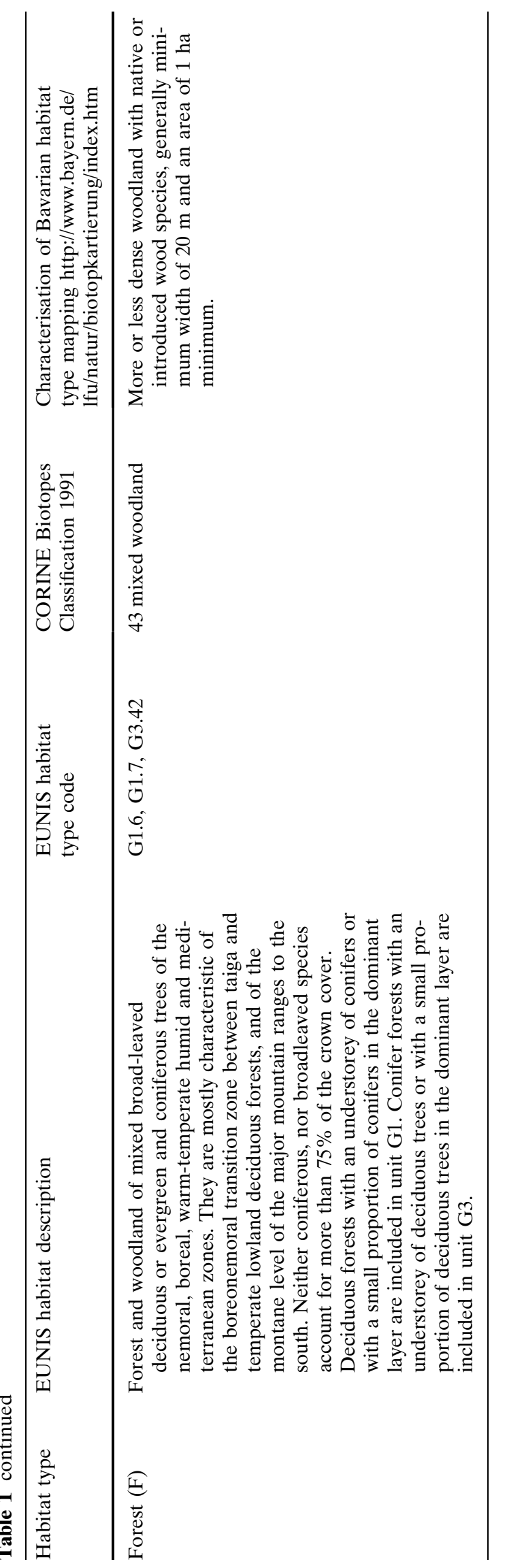

power, cf. Hosmer and Lemeshow 2000) in univariate analysis was selected for further analysis. We did not use independent factors from principal component analysis (PCA, cf. Vaughan and Ormerod 2003) because these were found to create difficulties in their biological interpretation and were consequently difficult to use in conservation biology. As integrating measures for horizontal and vertical vegetation cover, we used the 'total horizontal cover', which describes the plots' vertical structures (Sundermeier 1999), and the 'percentage open ground'.

Initial single predictor models included all habitat types investigated. Due to total separation causing numerical instabilities in some habitat types we restricted our analyses to those habitat types with at least minimal variation in occupancy. This was done to achieve a more detailed explanation of the species' habitat requirements. Eliminated biotopes were included in our models by formulating rules, like 'If forest then no suitable habitat'. These can be easily implemented into the regression equations. Thus, the reduction of our data set increased our error due to the exclusion of observations that could be predicted without error, however, we receive more detailed information on the habitat selection of the species.

\section{Model evaluation and test for spatial autocorrelation}

For model calibration, which judges the concurrence between observed and predicted values (Schröder 2000) we used Nagelkerke's pseudo- $R^{2}$ as a measure of goodness of fit (Nagelkerke 1991; Harrell 2001). Model discrimination, the power of the model to separate presence and absence of the species (Schröder 2000), was assessed with a threshold-independent measure, the AUC-value (Hanley and McNeil 1982; Fielding and Bell 1997). According to Hosmer and Lemeshow (2000) values above 0.7 describe an acceptable discrimination, values between 0.8 and 0.9 denote excellent discrimination. For a value above 0.9, discrimination is outstanding. For comparison of different models we used the Akaike Information Criterion (AIC, cf. Buckland et al. 1997; Augustin et al. 2001; Reineking and Schröder 2006).

Spatial autocorrelation has the effect of reducing the number of independent observations, which is not generally reflected by an equivalent decrease in the error degrees of freedom (Legendre 1993). Consequently, error terms are underestimated, leading to over-optimistic estimates of population parameters (Fielding and Haworth 1995) and abetting pseudoreplication (Guisan and Zimmermann 2000). To 
Table 2 Overview of experimental sites, their distribution across habitat types and frequency of occupancy for the three species studied. Results are shown for two years at sample site 'Hohe Wann' and one year at the sample site 'Leutratal'

\begin{tabular}{|c|c|c|c|c|c|c|c|c|c|}
\hline \multirow[t]{2}{*}{ Year } & \multirow[t]{2}{*}{ Location } & \multirow[t]{2}{*}{ Habitat type } & \multirow[t]{2}{*}{ No of plots } & \multicolumn{2}{|c|}{ P. albopunctata } & \multicolumn{2}{|c|}{ M. bicolor } & \multicolumn{2}{|c|}{ S. lineatus } \\
\hline & & & & occup. & unocc. & occup. & unocc. & occup. & unocc. \\
\hline \multirow[t]{11}{*}{2001} & Hohe Wann & all & 146 & 23 & 123 & 60 & 86 & 64 & 82 \\
\hline & & Extensively managed meadow & 45 & 6 & 39 & 24 & 21 & 25 & 20 \\
\hline & & Intensively managed meadow & 7 & 1 & 6 & 1 & 6 & 2 & 5 \\
\hline & & Inten. managed poor meadow & 24 & 0 & 24 & 5 & 19 & 7 & 17 \\
\hline & & Dry grassland & 26 & 9 & 17 & 18 & 8 & 21 & 5 \\
\hline & & Fringe vegetation & 10 & 7 & 3 & 9 & 1 & 9 & 1 \\
\hline & & Crop land & 8 & 0 & 8 & 1 & 7 & 0 & 8 \\
\hline & & Fallow land & 6 & 0 & 6 & 1 & 5 & 0 & 6 \\
\hline & & Hedge & 7 & 0 & 7 & 1 & 6 & 0 & 7 \\
\hline & & Forest & 7 & 0 & 7 & 0 & 7 & 0 & 7 \\
\hline & & Thermophilic forest & 6 & 0 & 6 & 0 & 6 & 0 & 6 \\
\hline \multirow[t]{11}{*}{2002} & Hohe Wann & all $\mathrm{T}$ & 143 & 28 & 115 & 70 & 73 & 50 & 93 \\
\hline & & Extensively managed meadow & 45 & 13 & 32 & 25 & 20 & 16 & 29 \\
\hline & & Intensively managed meadow & 8 & 1 & 7 & 4 & 4 & 1 & 7 \\
\hline & & Inten. managed poor meadow & 22 & 0 & 22 & 7 & 15 & 3 & 19 \\
\hline & & Dry grassland & 26 & 7 & 19 & 22 & 4 & 20 & 6 \\
\hline & & Fringe vegetation & 10 & 7 & 3 & 8 & 2 & 9 & 1 \\
\hline & & Crop land & 8 & 0 & 8 & 1 & 7 & 0 & 8 \\
\hline & & Fallow land & 6 & 0 & 6 & 2 & 4 & 1 & 5 \\
\hline & & Hedge & 7 & 0 & 7 & 1 & 6 & 0 & 7 \\
\hline & & Forest & 6 & 0 & 6 & 0 & 6 & 0 & 6 \\
\hline & & Thermophilic forest & 5 & 0 & 5 & 0 & 5 & 0 & 5 \\
\hline \multirow[t]{8}{*}{2002} & Leutratal & all & 28 & 18 & 10 & $\mathbf{0}$ & $\mathbf{0}$ & 16 & 12 \\
\hline & & Extensively managed meadow & 5 & 2 & 3 & 0 & 0 & 4 & 1 \\
\hline & & Intensively managed meadow & 5 & 0 & 5 & 0 & 0 & 2 & 3 \\
\hline & & Inten. managed meadow meagre & 5 & 2 & 3 & 0 & 0 & 1 & 4 \\
\hline & & Dry grassland & 6 & 4 & 2 & 0 & 0 & 6 & 0 \\
\hline & & Fringe vegetation & 3 & 2 & 1 & 0 & 0 & 3 & 0 \\
\hline & & Crop land & 2 & 0 & 2 & 0 & 0 & 0 & 2 \\
\hline & & Hedge & 3 & 1 & 2 & 0 & 0 & 1 & 2 \\
\hline
\end{tabular}

test whether our data show spatial autocorrelation, we calculated Moran's $I$ for standardised residuals as an index of covariance between different point locations (Lichstein et al. 2002; Karagatzides et al. 2003).

\section{Model validation}

One problem connected with models based on simple presence/absence data is that these data are only snap-shots from a certain time period and a certain region. Such models are static (Guisan and Zimmermann 2000) and need to be validated in space and time before they can be extrapolated to other areas (Morrison et al. 1998; Schröder and Richter 1999). We first applied a bootstrapping procedure (Verbyla and Litvaitis 1989; Efron and Tibshirani 1993; Reineking and Schröder 2006, Oppel et al. 2004) for internal validation. Additionally, we tested the transferability of the model in space (second study area; Freeman et al. 1997; Manel et al. 1999a, b; Schröder and Richter 1999) and time (second year; Dennis and
Eales 1999; Schröder 2000; Binzenhöfer et al. 2005) for external validation. To test the performance of these model transfers, we applied significance test of AUC-values (Beck and Shultz 1986; Schröder 2004; Binzenhöfer et al. 2005). A model transfer was regarded as successful if the AUC-value significantly exceeded a threshold of 0.7. All analyses were carried out with the statistical software R 1.7.1 (available at http://cran.r-project.org using the packages Hmsic and Design provided by F. Harrell).

\section{Influence of spatial scale}

To study the effects of the surrounding landscape composition on species occurrence on a larger spatial scale we used a method similar to Binzenhöfer et al. (2005). Therefore, we calculated the relative area of each habitat type in rings (radii $r=10 \mathrm{~m}, 25 \mathrm{~m}$ as well as $r=50 \mathrm{~m}$ ) around the plot and weighted them using the predicted occurrence probability determined in the univariate logistic regression analyses with the habitat type as plot parameter. In each case the inner rings 
(either the plot itself $(r=10 \mathrm{~m})$, or the ring with $r=25 \mathrm{~m}$ ) were subtracted from the outer rings $(r=25 \mathrm{~m}$ and $r=50 \mathrm{~m})$. These calculations were carried out with a GIS (ESRI ${ }^{\mathrm{TM}}$ ArcView 3.2). If we found overlapping rings we excluded one by random selection to avoid pseudoreplication. This resulted in a reduction of our data sets from $n=146$ to $n=118$. The method produces one single metric regression parameter for each radius (instead of categorical variables or percentages) and thus avoids the use of too many degrees of freedom in the analyses. To see whether the immediate surrounding landscape has a significant influence on species occurrence, the values for $r=25 \mathrm{~m}$ and $r=50 \mathrm{~m}$ are added to the values for $r=10 \mathrm{~m}$ (which corresponds to our experimental plot of $15 \times 15 \mathrm{~m})$ in a multiple regression analysis. Expansion of this analysis to scales probably more relevant for dispersal and metapopulation aspects (e.g. $r=100 \mathrm{~m}$ or $200 \mathrm{~m}$ ) was not possible in this study. Our experimental sites were restricted to the nature reserve and thus, too many overlapping rings would have resulted in a severe reduction of our data sets.

To check for habitat preferences of our species within one habitat type (smaller spatial scale) we compared the characteristics of occupied plots with those from unoccupied plots.

\section{Results}

The prevalence varied between species, but was almost constant over the years (Table 2). In contrast to the main study area, $S$. lineatus as well as $P$. albopunctata exhibited a very high prevalence in the second study area (S. lineatus: $57.1 \%$, P. albopunctata: $34.3 \%$ ).

Based on the occupancy pattern across some of habitat types and complete absences in certain habitats (Table 2) we deduced the following rules:

- Platycleis albopunctata does not occur in: rich meadows, extensively managed meadows, crop land, fallow land, hedges, and forests.

- Metrioptera bicolor does not occur in: rich meadows, crop land, fallow land, hedges, and forests.

- Stenobothrus lineatus does not occur in: rich meadows, crop land, fallow land, hedges, and forests.

Analysing the predictors 'habitat type' and 'type of management'

After internal validation, the predictor variable 'habitat type' showed a high explanatory power for all three species in models when it was used as single predictor variable (Table 3 ). These models were transferable in time for all species, for $S$. lineatus the transfer was also possible in space (Table 3 ).

For all three species, the 'fringe vegetation' has the highest probability of occurrence followed by dry grassland (Fig. 1). The 'management type' alone did not yield high explanatory power for the spatial distribution of the species, but was included in some of the multiple models and may be important in terms of conservational aspects. For $P$. albopunctata mowing always resulted in a high incidence. The other two species (M. bicolor and S. lineatus) are most often found on plots under extensive sheep-grazing management (Fig. 2). Intensively managed areas as well as areas with no management at all are avoided by all three species. Generally, the 'management type' cannot explain as much variation in incidence as the predictor 'habitat type'.

Influence of plot characteristics on the species' occurrence probabilities

Because habitat suitability may not be determined by a single factor alone, but probably by a combination of different factors we conducted multiple logistic regression analyses for each species with different combinations of independent variables from the reduced data sets.

\section{Stenobothrus lineatus}

Multiple logistic regression analyses for the data from 2001 resulted in six significant models with an AUCvalue exceeding 0.7. All models were free of residual spatial autocorrelation. Table 2 shows those four models with low AIC-values. The model with the lowest AIC predicts a high occurrence of $S$. lineatus in fringes, dry grassland, extensively managed meadows and grazed areas with low vegetation height. Only two of the multiple models were transferable in time, but none in space (Table 2). Internal validation of the models showed that only those with the variables 'habitat type', 'low vegetation height' and 'low total horizontal cover' were robust, but they were neither transferable in time nor space.

\section{Metrioptera bicolor}

Of the six significant multiple parameter models, which all showed no residual spatial autocorrelation, the highest occurrence of $M$. bicolor was predicted 


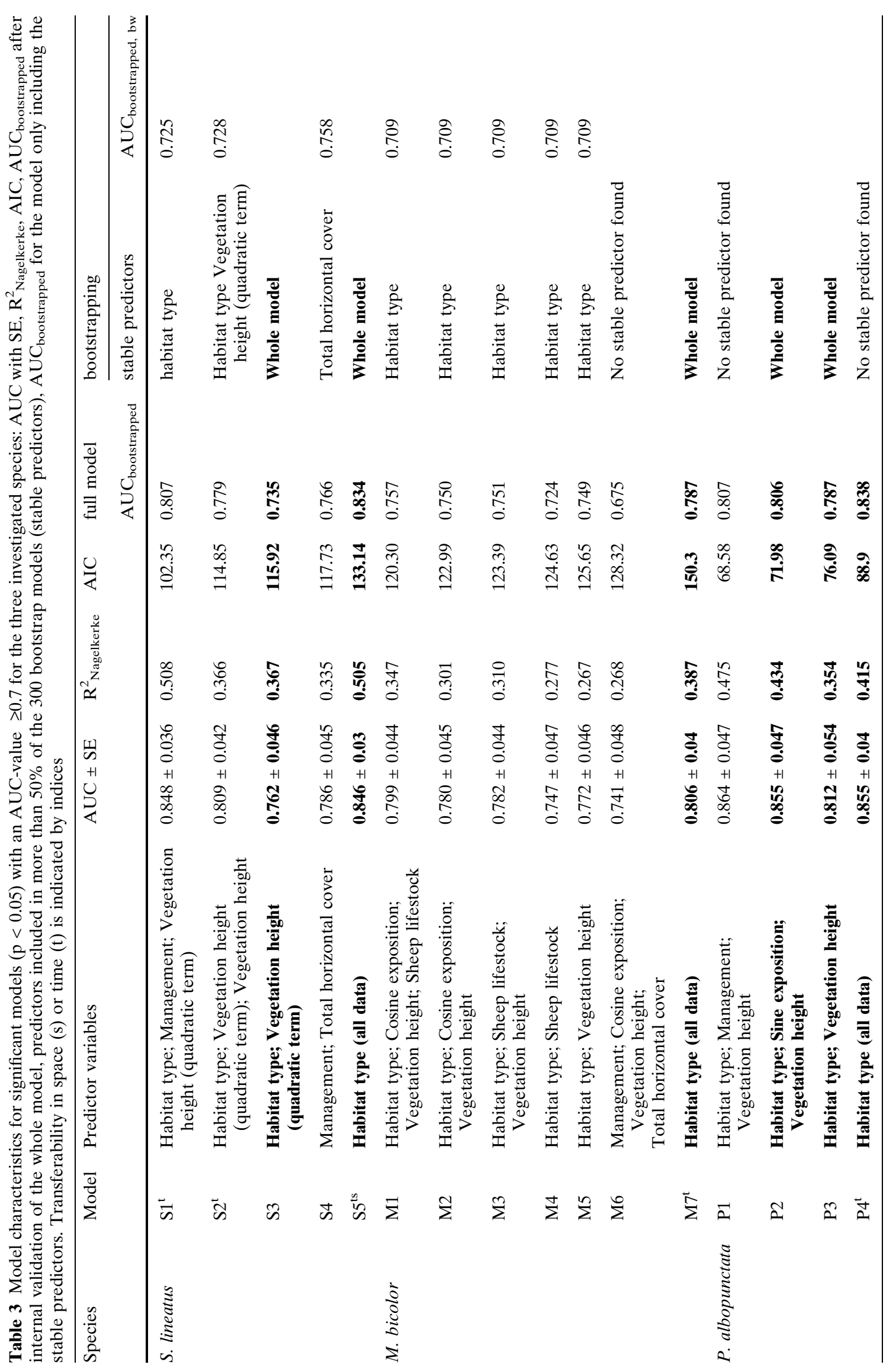




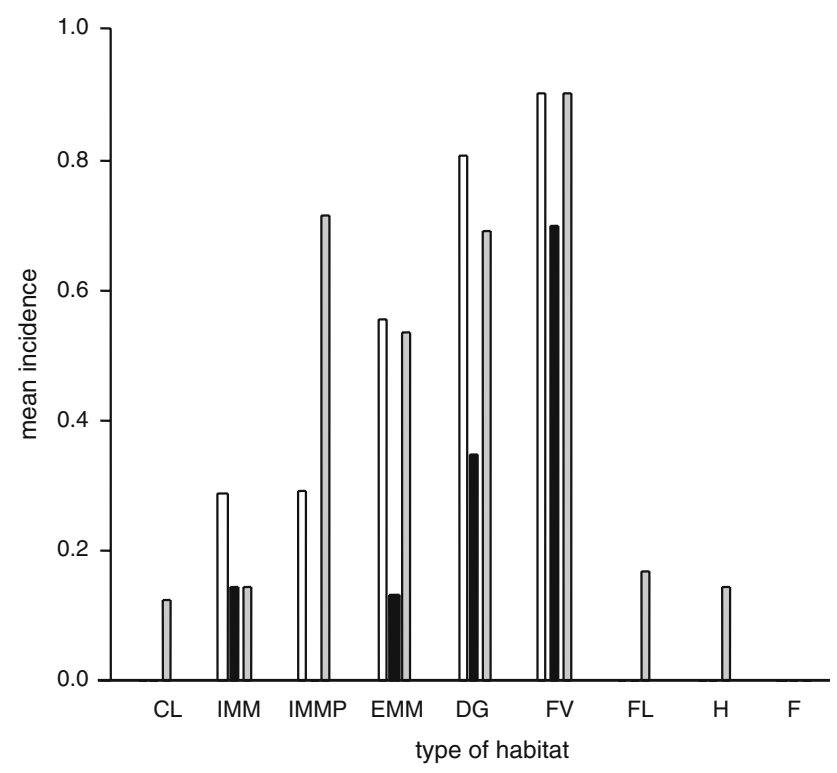

Fig. 1 Mean incidence in the habitat types: crop land (CL), intensively managed meadows (IMM), intensively managed poor meadows (IMMP), extensively managed meadows (EMM), dry grasslands (DG), fringe vegetation (FV), fallow land (FL), hedges $(\mathrm{H})$, forest $(\mathrm{F})$ for $S$. lineatus (white bars), M. bicolor (grey bars) and $P$. albopunctata (black bars)

for sheep-grazed fringe vegetation with tall vegetation and south-facing exposition. However, after internal validation with backwards variable selection, all multiple parameter models were identified as unstable (i.e. specific predictors were considered in

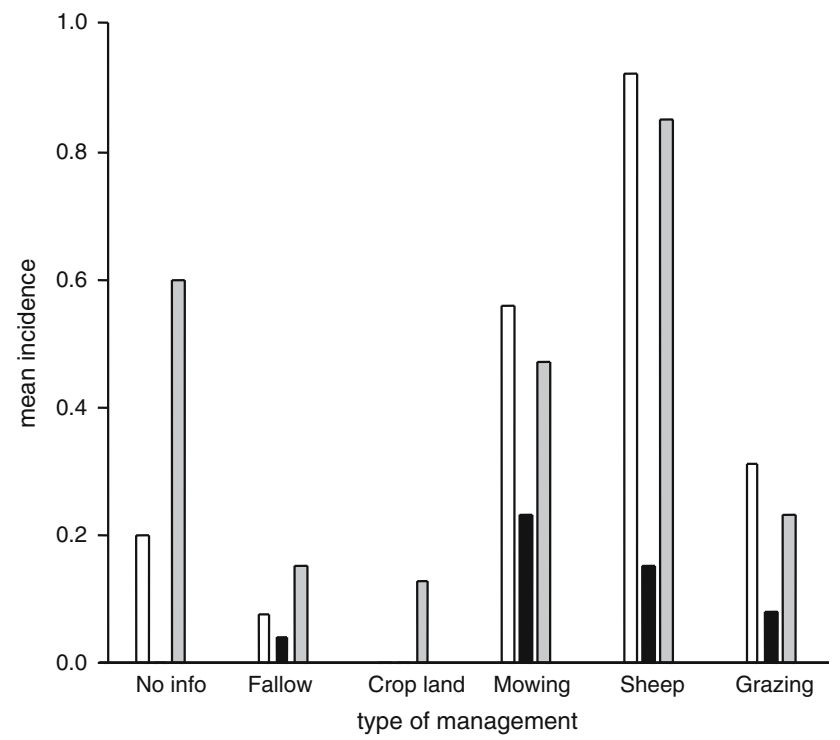

Fig. 2 Mean incidence for different types of management for $S$. lineatus (white bars), M. bicolor (grey bars) and $P$. albopunctata (black bars) less than $50 \%$ of 300 bootstraps and thus excluded) and had to be reduced to single predictor models with 'habitat type' as the single explanatory variable (Table 2). None of the more complex models was transferable in time. Spatial validation was not possible because $M$. bicolor could not be found in the second area.

\section{Platycleis albopunctata}

The model considering 'habitat type', 'management type' and 'vegetation height' yielded the smallest AIC-value (Table 3). But after internal validation with backwards variable selection none of these variables was included in more than $50 \%$ of the 300 bootstraps. Out of the three significant multiple models with the low AIC-values (all without residual spatial autocorrelation) the model considering 'habitat type', 'sine exposition' and 'vegetation height' was considered to be the best one. P. albopunctata prefers sites of mown fringe vegetation, south-west exposition and general low vegetation height. None of the multiple parameter models was transferable in time or space.

Influence of spatial scale

Finally, we carried out a comparison of occupied and unoccupied plots separately for each 'habitat type'. This allowed a closer look at habitat selection and yields habitat-specific models. Low 'vegetation height', low 'total horizontal cover' as well as low 'cover at the heights of $20 / 30 / 40 \mathrm{~cm}$ ' are attributes preferred by $S$. lineatus on dry grasslands (Mann-Whitney $U$-test, $p<0.05$ for all cases). By conducting the same analyses for $M$. bicolor we could not detect any significant differences between occupied and unoccupied plots (Mann-Whitney $U$-test, $p>0.05$ for all cases). $P$. albopunctata prefers extensively managed west-facing meadows (Mann-Whitney $U$-test, $p<0.05$ for all cases).

For $P$. albopunctata and $M$. bicolor no additional influence of the surroundings on habitat occupancy could be detected for the radii analysed in this study. Instead, for S. lineatus the surrounding area between 25 and $50 \mathrm{~m}$ was a significant variable in the model together with the plots' own habitat type $\left(A U C_{\text {bootstrapped }}=0.823\right.$ compared to $A U C_{\text {bootstrapped }}=0.725$ for the habitat type as single predictor variable). 


\section{Discussion}

Influence of plot characteristics on the occurrence probability of species

In our study, the habitat-specialist exhibiting the most restricted habitat requirements was $P$. albopunctata. It only occurred on fringe vegetation, dry grasslands and 'intensively managed poor meadows'. The two other species, M. bicolor and S. lineatus, were also found on extensively managed meadows. This result corresponds well with the literature on habitat requirements of these species (Detzel 1998).

After the reduction of the data set to the habitat types that yielded some incidence, the variable 'habitat type', which comprises several aspects of the realised niches, significantly contributes to many models. 'Habitat type' obviously has a great influence on the occurrence probability of the species. Additionally for $S$. lineatus, low vegetation height as well as low total horizontal cover, strongly influence occurrence positively. This may be explained by the fact that egg development depends on temperature (van Wingerden et al. 1991) and females lay their eggs in the upper ground layer or at the bottom of grasses (Oschmann 1993).

For M. bicolor a south-facing position, tall vegetation and sheep grazing are the factors, which in combination with the habitat type, explained most of the variance in the data. For this species, fringes, dry grasslands, and extensively managed meadows offer good food resources as the larvae feed on grasses as well as on flowers of grasses and herbs (Ingrisch 1976). This holds especially when the management is sheep grazing. As males of this species call in tall vegetation (Detzel 1998) and females lay their eggs in grass stems (Hartley and Warne 1972), a preference for high vegetation may correspond to the vertical orientation of the species.

The occurrence of $P$. albopunctata is best described by the combination of the variables 'habitat type', 'sine exposition' and 'vegetation height' in the plots. This corresponds to the finding of Detzel (1998) who describes that low vegetation height as well as southwest exposition result in an increased temperature that promotes the larval development of $P$. albopunctata. Apart from the influence of the habitat type, management regime contributes to habitat suitability for all three species. P. albopunctata was mainly found on mown dry grasslands and fringes, which provide an elevated ground temperature, and low vegetation due to their position on the steeper, upper south-facing hillsides. The other two species preferred areas, which were extensively grazed by sheep. Detzel (1998) also describes a preference by $P$. albopunctata for areas managed by sheep grazing, but our results seem to be in contrast with this. Our result may, however, be biased by the fact that the dry grasslands as well as the fringes investigated are all managed by mowing, therefore mowing and fringes cannot be separated. Although we cannot precisely predict the best management practice for the conservation of $P$. albopunctata, it appears that mown habitats may be suitable for this species.

In general, grazing by sheep mainly occurs in extensively managed meadows, where it produces a heterogeneous mosaic of tall and short vegetation patches within a site (Adler et al. 2001). Such complex habitats offer a variety of different local conditions with varying microclimates for different activities like feeding, mating or reproduction. Intensively managed, agricultural or silvicultural areas, as well as abandoned areas with no management at all are avoided by all three species. For intensively managed areas and agricultural land, the regular disturbance intervals at times when adults are reproducing or eggs are developing, rather than negative microclimatic conditions, appear to be the reason for an absence of the species. This is supported by the fact that adults of $P$. albopunctata did not leave crop land, but females were observed ovipositing after being released there artificially (Hein et al. 2003). Woodland as well as abandoned areas are most likely too cold and wet for the development of offspring.

Both, the 'habitat type' as well as the 'management type' are proxies for the real resources such as microclimatic differences based on factors like plant species composition, vegetation structure and density and are driving factors for the incidence of grasshoppers and bush crickets. In particular the categories of the habitat type display various aspects of the realised niche for the studied species (see also Samways and Moore (1991) who found no significant relationship between grasshopper assemblage and microclimatic temperature but a strong positive correlation with grass species richness). Thus, the influence of the parameter habitat type on occurrence probability is determined by a variety of other factors such as predation risk, temperature regime, oviposition and microclimatic conditions that are relevant for the species' habitat selection and survival. This may 
explain the contrasting effects of management regime for $P$. albopunctata. It is neither the 'habitat type' nor the exact management regime that determines species occurrence, but the resulting level of the relevant factors, such as increased temperature for egg development, which determines habitat quality for the species.

\section{Model validation}

Validation either internally or externally is the best means of determining the robustness and generality of a model (cf. Freeman et al. 1997; Glozier et al. 1997; Leftwich et al. 1997; Dennis and Eales 1999; Roloff and Kernoban 1999; Schröder and Richter 1999; Zimmermann and Kienast 1999; Bio et al. 2002; Lehmann et al. 2002a; Fleishman et al. 2003; Oppel et al. 2004; Peppler-Lisbach and Schröder 2004; Binzenhöfer et al. 2005). For all three species the simple model including 'habitat type' as the explanatory variable could be validated internally and showed a good transferability in time. For $S$. lineatus it could also be transferred in space. Spatial validation was not possible in any other case due to the low sample size in the second study area ( 28 plots) and the fact that the ranges of tested categories for 'habitat type' and 'management' in the second study area were too small (see Table 2). In such a case, it is more likely that we compared two different sampling designs rather than performing an external validation (Lehmann et al. 2002b). For future studies we would recommend the use of the same sampling design with similar sampling effort to perform a spatial validation of habitat suitability models. The failure of transferability in time for the multiple parameter models of $M$. bicolor might be caused by their instability. None of these models were stable with respect to the selected explanatory variables and only the variable 'habitat type' resulted in stable models after bootstrapping with stepwise backward variable selection.

Methodological aspects of the study

\section{Experimental design}

Although the type of stratified random sampling used in our study is an adequate and commonly used method (see also Wessels et al. 1998; Hirzel and Guisan 2002), we would recommend the use of a twostep approach whenever possible for further studies. This should start with a preliminary study (which was not possible in our case) with which clear non-habitat structures can be determined to exclude them from the analyses (Dufrene and Legendre 1991; Aspinall and Lees 1994). The intensive work on the detailed habitat requirements of a species can then be conducted in a main study with a high sample size in habitats with intermediate occupancy (see also Hirzel and Guisan 2002). Such an approach with higher sample sizes always improves the quality of the results (Hirzel and Guisan 2002). In the case of the bush cricket $P$. albopunctata with its low prevalence of around $20 \%$ in the nature reserve 'Hohe Wann', a higher sample size would almost certainly have improved the precision of our model. In the case of the other two investigated species, prevalence was around $40-50 \%$. This is regarded as optimal for the development of logistic regression models (Hosmer and Lemeshow 2000).

\section{The influence of spatial scale}

For the determination of species specific habitat preferences, one should always take into account that habitat selection behaviour is a scale-dependent process (Johnson 1980; Orians and Wittenberger 1991; Mackey and Lindenmayer 2001; Oppel et al. 2004). Thus an analysis of occurrence probability should be carried out on different spatial scales (Orians and Wittenberger 1991). This fact has been studied separately in a number of analyses (Poff 1997; Lindenmayer 2000; Cushman and McGarigal 2002; Luck 2002; Thompson and McGarigal 2002; Sergio et al. 2003; Store and Jokimaki 2003; Grand and Mello 2004; Oppel et al. 2004; Parody and Milne 2004; Poirazidis et al. 2004; Aubry et al. 2005; Graf et al. 2005; Legalle et al. 2005; Mörtberg and Karlström 2005). To account for this, we further expanded our analyses and looked for microhabitat preferences within one experimental plot. Therefore, we used only data from occupied plots and compared the parameters from the random point with those of the 'cricket (detection) point' in the same experimental plot. In our study, none of the species showed any significant preference for distinct microhabitat parameters (Wilcoxon match paired test after Bonferroni correction according to Rice (1989) for multiple comparisons, all comparisons $p>0.05$ ). Regarding $M$. bicolor, this contrasts with the findings of Krätzel (1999) and Krätzel et al. (2002) who found evidence for the preference for distinct microstructures. This may be due to the fine-grained scale of our study. Our plots 
were rather small (just $225 \mathrm{~m}^{2}$ ) compared to the 800$1320 \mathrm{~m}^{2}$ in the study of Krätzel (1999) and Krätzel et al. (2002). Thus, our plots may have been rather homogeneous. We would nevertheless expect that our species do actively select distinct microhabitats in a larger experimental site. This argument is supported by our separate analyses of each habitat type which showed a clear preference of $P$. albopunctata and $S$. lineatus for some structural aspects of occupied compared to unoccupied plots.

In many other studies, scale dependency of predictors is discussed and the influence of the surrounding of the tested areas has been shown (e.g. Binzenhöfer et al. 2005). In our case no additional influence of the plot surrounding on habitat occupancy could be detected for $P$. albopunctata and M. bicolor. This is probably because the information given by the plots' habitat type is the same as that of a radius of $25 \mathrm{~m}$. Thus, our radii do not represent the true surroundings in the sense of dispersal distance of the insects. Whether the inclusion of the surrounding between 25 and $50 \mathrm{~m}$ in the model of $S$. lineatus is based on metapopulation effects or the spatial heterogeneity of S. lineatus habitats cannot be deduced using the data from this study.

\section{Implications for conservation}

From our analyses we would conclude that for the conservation of these grasshopper and bush cricket species in the nature reserve 'Hohe Wann' management should aim to maintain the extensively managed meadows and especially dry grasslands and fringe vegetation. Whether this is achieved by mowing, sheep grazing or another studied management regime does not seem to be of great importance for the studied species as long as management does not occur too often (more than twice a year) and at times when reproduction or development of eggs is not disturbed (early or late in the season; for comparison see Chambers and Samways 1998). Regarding our results on parameters determining species occurrence, we know that we found no new relevant parameters for species occurrence compared with literature data for the temperate zones, but we gathered quantitative information on the parameters' influences. This information can be use in modelling approaches to test different management scenarios in their outcome for species survival (see Rudner et al. 2005; Schröder et al. submitted).

We are able to show that the habitat type is always a powerful predictor of species occurrence when we use it as a single predictor variable or even in the reduced data sets and multiple regression analyses. Thus, we can, on the one hand, conclude that the habitat type as a highly integrating variable, accounts for some parameters we did not survey (e.g. microclimate). On the other hand simple vegetation type maps (depicting habitat types) are sufficient to predict species occurrence with satisfactory precision, which is especially useful for nature conservation. Because the habitat type also represents a specific successional stage respectively a certain kind of management our models are able to predict in an indirect way the quality of habitats under different management. The use of these models would provide a quick and efficient possibility to determine the future/unknown distribution of species under different management regimes (see application of our data by Schröder et al. submitted) as well as in other regions where species distribution data are not available (Wilson et al. 2005, see also Binzenhöfer et al. 2005; Strauss and Biedermann 2005). Additionally, habitat models can be used to extrapolate ecological knowledge from point data to the landscape scale by creating habitat suitability maps (see Schröder 2000; Strauss and Biedermann 2005). These could be used as a basis for planning nature reserves and for the identification of core habitats (Cabeza et al. 2004). In such cases, the approach of statistical habitat suitability models is especially appealing as the data from our species could be combined with those of other animals (Hein et al. in press) and/or plant species and thus a multi-species approach could be used to identify the most "valuable" areas in terms of species diversity.

Acknowledgements We are grateful to Birgit Binzenhöfer for her cooperation in the field and Barbara Strauss for her help with the GIS-analysis of the plot surroundings. We thank Edward Connor for his help to improve the English and Michael Rudner for botanical advice. Thomas Hovestadt and two anonymous reviewers provided helpful comments on an earlier version of the manuscript. This study is part of the MOSAIK-project and is financially supported by the German Federal Ministry of Education and Research (BMBF, grant 01LN 0007). 


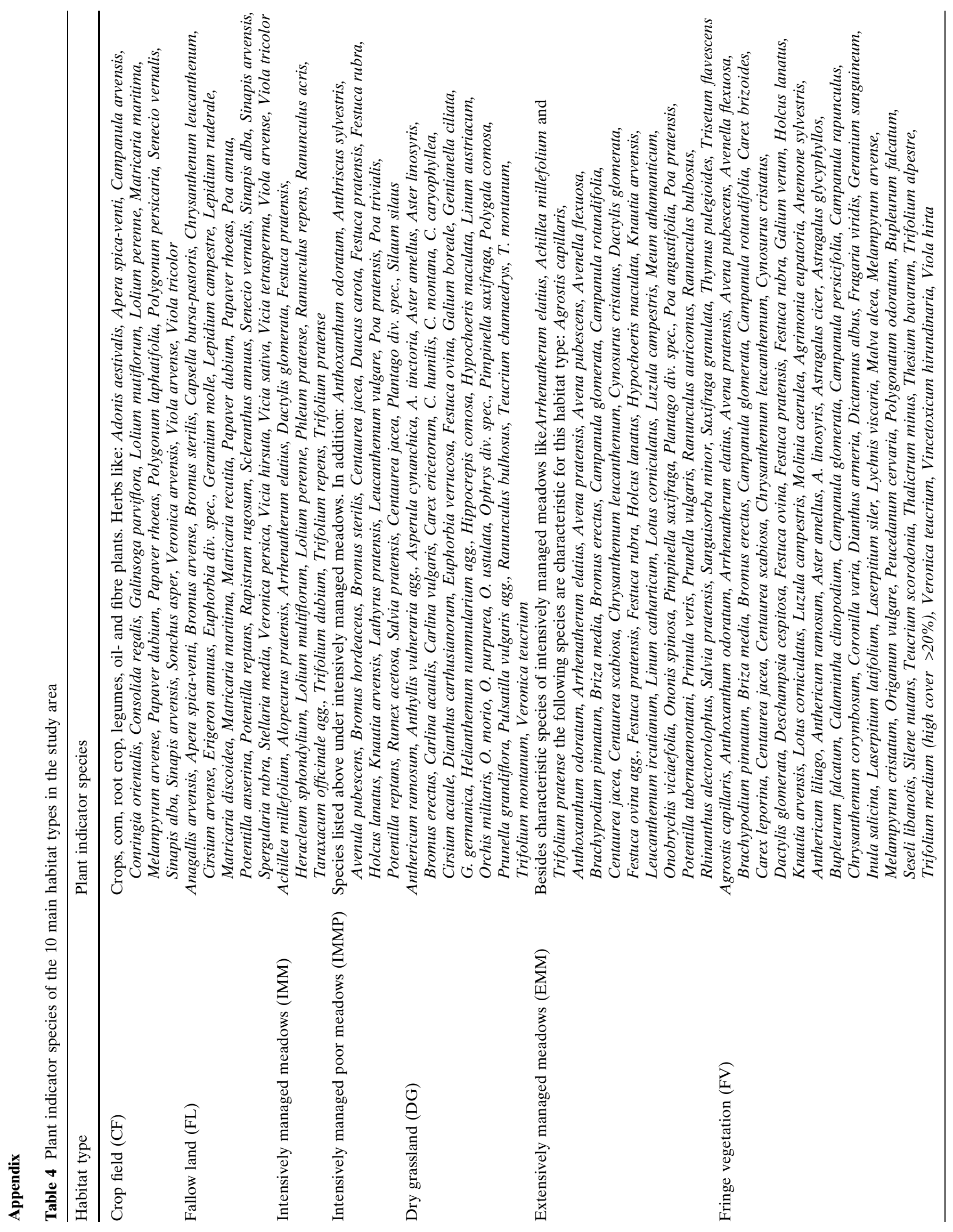




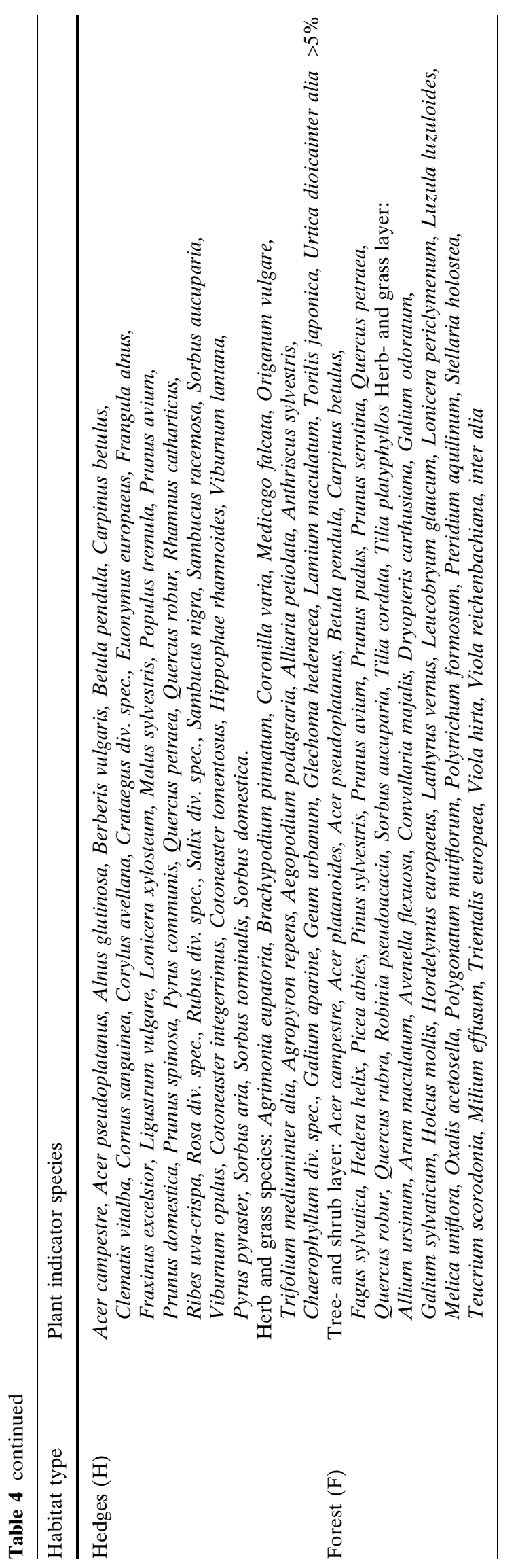

\section{References}

Adler PB, Raff DA, Lauenroth WK (2001) The effect of grazing on the spatial heterogeneity of vegetation. Oecologia 128:465-479

Aspinall RJ, Lees BG (1994) Sampling and analysis of spatial environmental data. In: Waugh TC, Healey RG (eds) Advances in GIS Research. Taylor and Francis, Southampton, pp 1086-1098

Aubry S, Magnin F, Bonnet V, Preece RC (2005) Multi-scale altitudinal patterns in species richness of land snail communities in south-eastern France. J Biogeogr 32:985-998

Augustin NH, Cummins RP, French DD (2001) Exploring spatial vegetation dynamics using logistic regression and a multinomial logit model. J Appl Ecol 38:991-1006

Austin MP (1976) On non-linear species response models in ordination. Vegetatio 33:33-41

Austin MP (2002) Spatial prediction of species distribution: an interface between ecological theory and statistical modelling. Ecol Modell 157:101-118

Bakker JP (1989) Nature management by grazing and cutting. Kluwer Academic Publishers, Dordrecht

Bayerisches Landesamt für Umweltschutz: Biotopkartierung. http://www.bayern.de/lfu/natur/biotopkartierung/index.html. Cited May 1997

Bayerisches Landesamt für Umweltschutz: Rote Liste gefährdeter Springschrecken (Saltatoria) Bayerns. http:// www.bayern.de/lfu/natur/arten_und_biotopschutz/roteliste/ rote_liste_tiere_pdf/ral tatoria.pdf. Cited 2003

Beaufoy G, Baldock D, Clark J (1994) The nature of farming: low intensity farming systems in nine European Countries. Institute for European Environment Polica, London

Beck JR, Shultz EK (1986) The use of ROC curves in test performance evaluation. Arch Pathol Laboratory Medicine 110:13-20

Bignal EM, McCracken DI (1996) Low-intensity farming systems in the conservation of the countyside. J Appl Ecol 33:413-424

Binzenhöfer B, Schröder B, Biedermann R, Strauß B, Settele J (2005) Habitat models and habitat connectivity analysis for butterflies and burnet moths-the example of Zygaena carniolica and Coenonympha arcania. Biol Conserv 126:247-259

Bio AMF, De Becker P, De Bie E, Huybrechts W, Wassen M (2002) Prediction of plant species distribution in lowland river valleys in Belgium: modelling species response to site conditions. Biodivers Conserv 11:2189-2216

Bobbink R, Willems JH (1993) Restoration management of abandoned chalk grassland in the Netherlands. Biodivers Conserv 2:616-626

Buckland ST, Burnham KP, Augustin NH (1997) Model selection: An integral part of inference. Biometrics 53:603-618

Cabeza M, Araújo MB, Wilson RJ, Thomas CD, Cowley MJR, Moilanen A (2004) Combining probabilities of occurrence with spatial reserve design. J Appl Ecol 41:252-262

Chambers BQ, Samways MJ (1998) Grasshopper response to a 40-year experimental burning and mowing regime, with recommendations for invertebrate conservation management. Biodivers Conserv 7:985-1012

Cushman SA, McGarigal K (2002) Hierarchical, multi-scale decomposition of species environment relationships. Landscape Ecol 17:637-646

Dennis RLH, Eales HT (1999) Probability of site occupancy in the large heath butterfly Coenonympha tullia determined from geographical and ecological data. Biol Conserv 7:295302 
Detzel P (1998) Die Heuschrecken Baden-Württembergs. Stuttgart, Ulmer

Dufrene M, Legendre P (1991) Geographic structure and potential ecological factors in Belgium. J Biogeogr 18:257-266

Efron B, Tibshirani RJ (1993) An Introduction to the Bootstrap. Chapmann and Hall, New York

Elsner O (1994) Geplantes Naturschutzgebiet "Südlicher Hassbergtrauf" im Landkreis Hassberge. Institut für Vegetationskunde und Landschaftsökologie, Zeckern

Fielding AH, Haworth PF (1995) Testing the generality of birdhabitat models. Conserv Biol 9:1466-1481

Fielding AH, Bell JF (1997) A review of methods for the assessment of prediction errors in conservation presence/ absence models. Environ Conserv 24:38-49

Fleishman E, Mac Nally R, Fay JP (2003) Validation tests of predictive models of butterfly occurrence based on environmental variables. Conserv Biol 17:806-817

Fraser RH (1998) Vertebrate species richness at the mesoscale: relative role of energy and heterogeneity. Glob Ecol Biogeogr 7:215-220

Freeman MC, Bowen ZH, Crance JH (1997) Transferability of habitat suitability criteria for fishes in warmwater streams. $\mathrm{N}$ Am J Fish Manage 17:20-31

Fuller RM (1987) The changing extent and conservation interest of lowland grasslands in England and Wales: a review of grassland surveys 1930-84. Biol Conserv 40:281-300

Gauch HG, Chase GB (1974) Fitting the Gaussian curve to ecological data. Ecology 55:1377-1381

Glozier NE, Culp JM, Scrimgeour GJ (1997) Transferability of habitat suitability curves for a benthic minnow, Rhinichthys cataractae. J Freshwat Ecol 12:379-394

Graf RF, Bollmann K, Suter W, Bugmann H (2005) The importance of spatial scale in habitat models: Capercaillie in the Swiss Alps. Landscape Ecol 20:703-717

Grand J, Mello MJ (2004) A multi-scale analysis of speciesenvironment relationships: rare moths in a pitch pine-scrub oak (Pinus rigida-Quercus ilicifolia) community. Biol Conserv 119:495-506

Guisan A, Zimmermann NE (2000) Predictive habitat distribution models in ecology. Ecol Modell 135:147-186

Hanley JA, McNeil BL (1982) The meaning and use of the area under a ROC curve. Radiology 143:29-36

Harrell FEJ (2001) Regression modelling strategies: with applications to linear models, logistic regression, and survival analysis. Springer-Verlag, Berlin

Hartley JC, Warne AC (1972) The developmental biology of the egg stage of Western European Tettigoniidae (Orthoptera). J Zool 168:267-298

Harz K (1969) The Orthoptera of Europa, The Hague

Heglund PJ, Jones JR, Fredrickson LH, Kaise MS (1994) Use of boreal forested wetlands by Pacific loons (Gavia pacifica Lawrence) and horned grebes (Podiceps auritus L.): Relations with limnological characteristics. Hydrobiologia 279/ 280:171-183

Hein S, Gombert J, Hovestadt T, Poethke HJ (2003) Movement patterns of Platycleis albopunctata in different types of habitat: matrix is not always matrix. Ecol Entomol 28:432438

Hein S, Binzenhöfer B, Poethke HJ, Biedermann R, Settele J, Schröder B (in press) The generality of habitat suitability models: A practical test with two insect groups. Basic and Applied Ecology

Heinrich W, Marstaller R, Bährmann R, Perner J, Schäller G (1998) Naturschutzreport - Jena: Das Naturschutzgebiet "Leutratal" bei Jena - Struktur- und Sukzessionsforschung in Grasland-Ökosystemen. Jena
Hirzel A, Guisan A (2002) Which is the optimal sampling strategy for habitat suitability modelling. Ecol Modell 157:331-341

Hosmer DW, Lemeshow S (2000) Applied logistic regression, 2nd edn. Wiley, New York

Huston MA (1994) Biological diversity the coexistence of species on changing landscapes. Cambridge University press, Cambridge

Ingrisch S (1976) Vergleichende Untersuchung zum Nahrungsspektrum mitteleuropäischer Laubheuschrecken (Saltatoria: Tettigoniidae). Entomologische Zeitschrift 20:217-224

Ingrisch S, Köhler G (1998) Die Heuschrecken Mitteleuropas. Westarp-Wiss, Magdeburg

Jacquemyn H, Brys R, Hermy M (2003) Short-term effects of different management regimes on the response of calcareous grassland vegetation to increased nitrogen. Biol Conserv 111:137-147

Johnson DH (1980) The comparison of usage and availability measurements for evaluating resource preference. Ecology 61:65-71

Kahmen S, Poschlod P, Schreiber K-F (2002) Conservation management of calcareous grasslands. Changes in plant species composition and response of functional traits during 25 years. Biol Conserv 104:319-328

Karagatzides JD, Manson HR, Tsuji LJS (2003) Spatial distribution and performance of Scirpus americanus ramets across a temperate intertidal marsh resource gradient. Plant Ecol 169:215-226

Kindvall O, Ahlen I (1992) Geometrical factors and metapopulation dynamics of the bush cricket, Metrioptera bicolor Philippi (Orthoptera: Tettigoniidae). Conserv Biol 6:520-529

Kleyer M, Biedermann R, Henle K, Poethke HJ, Poschlod P, Settele J (2002) MOSAIK-Semi-open pasture and ley-a research project on keeping the cultural landscape open. In: Redecker B, Härdtle W, Finck P, Riecken U, Schröder E (eds) Pasture landscape and nature conservation. Springer, Heidelberg, pp 399-412

Krätzel K (1999) Habitatpräferenzen der beiden wärmeliebenden Heuschreckenarten Metrioptera bicolor und Platycleis albopunctata. Diploma Thesis. Bayerische-Julius- Maximilians-Universität Würzburg

Krätzel K, Butterweck MD, Hovestadt T (2002) Habitatwahl von Metrioptera bicolor auf unterschiedlichen Maßstabsebenen (Ensifera: Tettigoniidae). Articulata 17:21-37

Kruess A, Tscharntke T (2002) Grazing intensity and the diversity of grasshoppers, butterflies, and trap-nesting bees and wasps. Conserv Biol 16(6):1570-1580

Kull K, Zobel M (1991) High species richness in an Estonian wooded meadow. J Veg Sci 2:277-714

Leftwich KN, Angermeier PL, Dolloff CA (1997) Factors influencing behavior and transferability of habitat models for a benthic stream fish. Trans Am Fish Soc 126:725-734

Legalle M, Santoul F, Figuerola J, Mastrorillo S, Céréghino R (2005) Factors influencing the spatial distribution patterns of the bullhead (Cottus gobio L, Teleostei Cottidae): a multiscale study. Biodivers Conserv 14:1319-1334

Legendre P (1993) Spatial autocorrelation: Trouble or new paradigm? Ecology 74:1659-1673

Lehmann A, Leathwick JR, Overton JM (2002a) Assessing New Zealand fern diversity from spatial predictions of species assemblages. Biodivers Conserv 11:2217-2238

Lehmann A, Overton JM, Leathwick JR (2002b) GRASP: generalized regression analysis and spatial prediction. Ecol Modell 157:189-207

Lele SR, Allen KL (2006) On using expert opinion in ecological analyses: a frequentist approach. Environmetrics (in press) 
Lichstein JW, Simons TR, Shriner SA, Franzreb K (2002) Spatial autocorrelation and autoregressive models in ecology. Ecol Monogr 72:445-463

Lindenmayer DB, Cunningham PB, Tanton MT, Nix HA, Smith AP (1991) The conservation of arboreal marsupials in the montane ash forests of the central highlands of Victoria, South East Australia: III. The habitat requirements of leadbeater's possum Gymnobelideus leadbeateri and models of the diversity and abundance of arboreal marsupials. Biol Conserv 56:295-315

Lindenmayer DB (2000) Factors at multiple scales affecting distribution patterns and their implications for animal conservation-Leadbeater's Possum as a case study. Biodivers Conserv 9:15-35

Luck GW (2002) The habitat requirements of the rufous treecreeper (Climacteris rufa). 1. Preferential habitat use demonstrated at multiple spatial scales. Biol Conserv 105:383-394

Maas S, Detzel P, Staudt A (2002) Gefährdungsanalyse der Heuschrecken Deutschlands. Verbreitungsatlas, Gefährdungseinstufung und Schutzkonzepte. BfN-Schriftenvertrieb, Landwirtschaftsverlag, Münster

Mackey BG, Lindenmayer DB (2001) Towards a hierarchical framework for modelling the spatial distribution of animals. J Biogeogr 28:1147-1166

Manel S, Diass JM, Buckton ST, Ormerod SJ (1999a) Alternative methods for predicting species distribution: an illustration with Himalayan river birds. J Appl Ecol 36:734-747

Manel S, Dias JM, Ormerod SJ (1999b) Comparing discriminant analysis, neural networks and logistic regression for predicted species distributions: a case study with a Himalayan river bird. Ecol Modell 120:337-347

Manel S, Williams HC, Ormerod SJ (2001) Evaluating presenceabsence models in ecology: the need to account for prevalence. J Appl Ecol 38:921-931

McConnaughay KDM, Bazzaz FA (1987) The relationship between gap size and performance of several colonizing annuals. Ecology 68:411-416

Mörtberg U, Karlström A (2005) Predicting forest grouse distribution taking account of spatial autocorrelation. J Nat Conserv 13:147-159

Morrison ML, Marcot BG, Mannan RW (1998) Wildlife-habitat relationsships-concepts and applications. The University of Wisconsin Press, Madison

Mühlenberg M (1993) Freilandökologie. UTB, Heidelberg

Mühlenberg M, Henle K, Settele J, Poschlod P, Seitz A, Kaule G (1996) Studying species survival in fragmented landscapes: The approach of the FIFB. In: Settele J, Margules C, Poschlod P, Henle K (eds) Species survival in fragmented landscapes. Kluwer Academic Publishers, Dordrecht

Nagelkerke NJD (1991) A note on a general definition of the coefficient of determination. Biometrika 78:691-692

National Biodiversity Network Habitat Dictionary. www.nbn.org.uk/habitats

Oppel S, Schaefer HM, Schmidt V, Schröder B (2004) Habitat selection by the Pale-headed brush-finch, Atlapetes pallidiceps, in southern Ecuador: implications for conservation. Biol Conserv 118:33-40

Orians GH, Wittenberger JF (1991) Spatial and temporial scales in habitat selection. Am Nat 137:29-49

Oschmann M (1993) Art-Unterschiede in der Phänologie der Heuschrecken (Saltatoria). Articulata 8:35-43

Owen JG (1989) Patterns of herpetofauna species richness: relation to temperature, precipitation and variance in elevation. J Biogeogr 16:141-150

Parody MJ, Milne BT (2004) Implications of rescaling rules for multi-scaled habitat models. Landscape Ecol 19:691-701
Pearce JL, Burgman MA, Franklin DC (1994) Habitat selection by helmeted honeyeater. Wildl Res 21:53-63

Peppler-Lisbach C, Schröder B (2004) Predicting the species composition of mat-grass communities (Nardetalia) by logistic regression modelling. J Veg Sci 15:623-634

Poff NL (1997) Landscape filters and species traits: towards mechanistic understanding and prediction in stream ecology. J N Am Benthological Soc 16:391-409

Poirazidis K, Goutner V, Skartsi T, Stamou G (2004) Modelling nesting habitat as a conservation tool for the Eurasian black vulture (Aegypius monachus) in Dadia Nature Reserve, northeastern Greece. Biol Conserv 118:235-248

Poschlod P, Bakker J, Bonn S, Fischer S (1996) Dispersal of plants in fragmented landscapes. In: Settele J, Margules C, Poschlod P, Henle K (eds) Species survival in fragmented landscapes. Kluwer Academic Publishers, Dordrecht

Poschlod P, Schumacher W (1998) Rückgang von Pflanzen - und Pflanzengesellschaften des Grünlandes.- Gefährdungsursachen und Handlungsbedarf. Schriftenreihe für Vegetationskunde 29:83-99

Pykälä J (2003) Effects of restoration with cattle grazing on plant species composition and richness of semi-natural grasslands. Biodivers Conserv 12:2211-2226

Redecker B, Härdtle W, Finck P, Riecken U, Schröder E (2002) Pasture landscape and nature conservation. Springer, Heidelberg. pp 399-412

Reineking B, Schröder B (2006) Constrain to perform: regularization of habitat models. Ecol Modell 193:675-690

Rice W (1989) Analyzing tables of statistical tests. Evolution 43:223-225

Roloff GJ, Kernoban BJ (1999) Habitat suitability and evaluation - evaluating reliability of habitat suitability index models. Wildl Soc Bull 27:973-985

Rudner M, Biedermann R, Schröder B, Kleyer M (in press) Integrated grid based ecological and economic (INGRID) landscape model - a tool to support landscape management decisions. Environ Modell Software

Rushton SP, Ormerod SJ, Kerby G (2004) New paradigms for modelling species distributions? J Appl Ecol 41:193-200

Samways MJ, Moore SD (1991) Influence of exotic conifer patches on grasshopper (Orthoptera) assemblages in grassland matrix at a recreational resort, Natal, South Africa. Biol Conserv 57:117-137

Schreiber KF (1977) Zur Sukzession und Flächenfreihaltung auf Brachland in Baden-Württemberg. Verhandlungen der Gesellschaft für Ökologie, Göttingen

Schröder B, Richter O (1999) Are habitat models transferable in space and time? Zeitschrift für Ökologie und Naturschutz 8:195-205

Schröder B (2000) Zwischen Naturschutz und Theoretischer Ökologie: Modelle zur Habitateignung und räumlichen Populationsdynamik für Heuschrecken im Niedermoor. $\mathrm{PhD}$. Thesis, Technische Universität Braunschweig

Schröder B (2004) ROC \& AUC-calculation-evaluating the predictive performance of habitat models. Available from: < http://brandenburg.geoecology.uni-potsdam.de/ users/ schroeder/download.html >

Schröder B, Rudner M, Biedermann R, Kleyer M (2004) Ökologische und sozio-ökonomische Bewertung von Managementsystemen für die offenhaltung von Landschaften-ein integriertes Landschaftsmodell. UFZ-Bericht 9/2004:121132

Sergio F, Pedrini P, Marchesi L (2003) Adaptive selection of foraging and nesting habitat by black kites (Milvus migrans) and its implications for conservation: a multi-scale approach. Biol Conserv 112:351-362 
Settele J (1998) Metapopulationsanalyse auf Rasterdatenbasis. BG Teubner Verlagsgesellschaft, Stuttgart

Store R, Jokimaki J (2003) A GIS-based multi-scale approach to habitat suitability modeling. Ecol Modell 169:1-15

Strauss B, Biedermann R (2005) The use of habitat models in conservation of rare and endangered leafhopper species (Hemiptera, Auchenorrhyncha). J Insect Conserv 9:245-259

Sundermeier A (1999) Zur Vegetationsdichte der Xerothermrasen nordwestlich von Halle/Saale. Dissertationes Botanicae

Thompson CM, McGarigal K (2002) The influence of research scale on bald eagle habitat selection along the lower Hudson River, New York (USA). Landscape Ecol 17:569-586

Trexler JC, Travis J (1993) Nontraditional regression analyses. Ecology 74:1629-1637

Van Dijk G (1991) The status of semi-natural grasslands in Europe. In: Goriup PD, Batten LA, Peterborough NJA (eds), The conservation of lowland dry grassland birds in Europe. Joint Nature Conservation Committee :15-36

Van Wingerden WKRE, Musters JCM, Maascamp FIM (1991) The influence of temperature on the duration of egg development in West European grasshoppers (Orthoptera: Acrididae). Oecologia 87:417-423
Vaughan IP, Ormerod SJ (2003) Improving the quality of distribution models for conservation by addressing shortcomings in the field collection of training data. Conserv Biol 17:1601-1611

Verbyla DL, Litvaitis JA (1989) Resampling Methods for Evaluating classification accuracy of wildlife habitat models. Environ Manage 13:783-787

Vos CC, Zonnefeld JIS (1993) Patterns and processes in a landscape under stress: the study area. In: Vos CC, Opdam P (eds) Landscape Ecology of a Stressed Environment. Chapmann \& Hall, London

Wessels KJ, van Jaarsveld AS, Grimbeek JD, van der Linde MJ (1998) An evaluation of the gradsect biological survey method. Biodivers Conserv 7:1093-1121

Wilson KA, Westphal MI, Possingham HP, Elith J (2005) Sensitivity of conservation planning to different approaches using predicted species distribution data. Biol Conserv 122:99-112

Zimmermann N, Kienast F (1999) Predictive mapping of alpine grasslands in Switzerland: species versus community approach. J Veg Sci 10:469-482 